\title{
Terörle Mücadele Kanunu'na Göre Mutlak ve Nispi Terör Suçları
}

\author{
FARUK Y. TURINAY \\ f.turinay@gmail.com \\ ORCID-ID: 0000-0003-2427-2062
}

Öz: Terör kavramı gerek ulusal gerekse uluslararası bağlamda tanımlanması güç bir kavram olarak bilinmektedir. Aynı zorluk, terör örgütü, terör amaçlı örgütlenme suçu teşkil eden fiiller ve terör suçlarının kanuni tanımları hususunda da mevcuttur. Bu çalışmada terör suçu kavramı, mutlak terör suçu ve nispi terör suçu Terörle Mücadele Kanunu çerçevesinde ele alınmaktadır. Çalışmanın birinci bölümü, terör suçu kavramı ile mutlak terör suçu ve nispi terör suçu arasındaki farklara yönelik genel bir yaklaşıma yer vermektedir. Çalışmanın ikinci bölümünde Türk Ceza Kanunu’ndaki mutlak terör suçları - Devletin birliğini ve ülke bütünlüğ̈̈nü bozmak, askerî tesisleri tahrip ve düşman askerî hareketleri yararına anlaşma, anayasayı ihlal, yasama organına karşı suç, hükümete karşı suç, Türkiye Cumhuriyeti Hükümetine karşı silâhlı isyan, silahlı örgüt, silah sağlama, yabancı hizmetine askere yazma, yazılma ve Cumhurbaşkanına suikast- Terörle Mücadele Kanunu çerçevesinde değerlendirilmektedir. Nispi terör suçlarının kavramsal ve hukuki çerçevesi ise son bölümün konusunu oluşturmaktadır.

Anahtar kelimeler: Mutlak terör suçları, Nispi terör suçları, Terörle Mücadele Kanunu, Türk Ceza Kanunu.

\section{Giriş}

“Terörizm”, "terör suçu” kavramları gerek siyasi ve sosyolojik, gerekse hukuki açıdan tanımlanması güç kavramlardır.

Terör suçu ile ilgili olarak en genel ve pozitivist bir yaklaşımla, terör suçunun, kanunun terör suçu olarak kabul ettiği suçlar olduğu söylenebilir. İkinci olarak, terör suçu, zıddıyla tanımlanabilecektir: Adi suç kapsamına girmeyen ve belli kanuni nitelikleri taşıyan suçlar terör suçlarıdır. Fakat her halükarda terör suçu bir suç tipi değil, bir suç kategorisidir. Bir başka deyişle, Bir kişinin "terör suçu” işlemesinden değil, "terör suçları kapsamına giren bir suç" işlemesinden söz etmek daha doğru olacaktır.

Terör suçları çeşitlilik arz etmektedir. Türk ve yabancı hukuk düzenlemeleri de göz

\footnotetext{
* Dr., Yalova Üniversitesi Hukuk Fakültesi.

Bu makale, “Türk Ceza Hukukunda Terör Amaçlı Örgütlenme Suçu” adlı doktora tezinden üretilmiştir. 
önünde bulundurulursa, terör amaçlı örgütlenme suçu, terörizmin finansmanı, terörizm propagandası, terörizm amaçlı eğitim, terörizme eleman sağlama, ekolojik terör suçları gibi çok çeşitli suçlar terör suçları kapsamında yer almaktadır.

Türk hukuku bakımından terör suçları 3713 sayılı Terörle Mücadele Kanunu'nda doğrudan terör suçu sayılan suçlar ve terör örgütü faaliyeti kapsamında işlendiği takdirde terör suçu sayılan suçlar olmak üzere ikiye ayrılmaktadır. "Türk Ceza Hukukunda Terör Amaçlı Örgütlenme Suçu” adlı doktora tezimizde belli ölçüde incelediğimiz mutlak ve nispi terör suçlarının başlı başına ele alınarak hukuki mahiyetinin ayrıntılı olarak aydınlatılması bu çalışmamızın temel maksadıdır.

\section{Terör Suçu Kavramı ve Mutlak-Nispi Terör Suçu Ayrımına Genel Bakış}

\section{Terör Suçu Kavramı}

Terör suçunun, genel bir bakış açısıyla, terör saikiyle işlenmiş suç olarak tanımlanması mümkündür.

Terör suçları esasen tali bir suç kategorisi olup ceza kanunlarında suç olarak tanımlanan ve belli nitelikleri taşıyan suçları ifade etmektedir. ${ }^{1} \mathrm{Bu}$ nitelikler birtakım suçların anayasal düzeni ve kamu barışını sarsmayı veya ortadan kaldırmayı amaçlayan bir terör örgütünün faaliyeti kapsamında işlenmesiyle somutlaşmış olacak, böylece daha ağır cezalandırılması gereken suçlardan oluşan bir suç kategorisi oluşmuş sayılacaktır. ${ }^{2}$

Terör suçu, bir suç tipi değildir. ${ }^{3}$ Tahir Taner'in de belirttiği üzere "Hakikatte bir tethişçilik suçu yoktur, tethişçilik mahiyetinde bir takım suçlar vardır”."

Belli bir terör suçu incelendiğinde o suçtaki terör unsuru, suçun özünden değil niteliğinden kaynaklanmaktadır. ${ }^{5}$ Yine de adi suç oluşturan bir fiil, anayasal düzeni hedef alıyorsa bu niteliğin fiilin tamamı bakımından "icra hareketi” değerinde olduğu yönünde görüşler bulunmaktadır. ${ }^{6}$

Bir suç kategorisi olarak terör suçlarının, suçun unsurları bakımından da ele alındığı gözlemlenmektedir. Bu doğrultuda, herhangi bir suçun kurucu unsurları maddi unsur ve manevi unsur olarak ifade edilirken, terör suçları için bağlamsal unsur (élément contextuel) olarak ifade edilen üçüncü bir öğenin dikkate alınması gerektiği düşünülmektedir. ${ }^{7}$ Bağlamsal unsur, eylemi terör eylemi haline getiren ve yargıç

\footnotetext{
1 Miguel Polaino Navarrete, "Apología y Encubrimiento del Terrorismo", Ed. Faustino Gutiérrez-Alviz Conradi, La Criminalidad Organizada Ante la Justicia, Sevilla: Editorial Universidad de Sevilla, 1996, s.50.

2 Navarrete, "Apología y Encubrimiento del Terrorismo", s.50.

3 Şükrü Alparslan, Hukuk ve Kriminoloji Açısından Tedhişçilik, İstanbul: Teknik Yayınları, 1983, s.95; Tahir Taner, “Tedhişçilik ve 16 İkinci Teşrin 1937 Cenevre Mukavelenameleri”, İstanbul Üniversitesi Hukuk Fakültesi Mecmuası, (Cemil Birsel'e Armağan), 1939, s.467.

4 Taner, “Tedhişçilik ve 16 İkinci Teşrin 1937 Cenevre Mukavelenameleri”, s.467.

5 Çetin Özek, “Terör ve Terörle Mücadele Kanunu”, İstanbul Barosu Dergisi, 65/4-5-6 (1991), s.355.

6 Özek, “Terör ve Terörle Mücadele Kanunu”, s.360-361.

7 Ignacio de la Serna, "Des Infractions Terroristes”, Eds. Christian De Valkeneer and Ignacio de la Serna, À la Découverte de la Justice Pénale: Paroles de Juriste, Bruxelles: Éditions Larcier, 2015, s.204.
} 
tarafından takdir edilecek bağlam ve çerçeve olarak tarif edilmektedir. ${ }^{8}$ Terör suçu işleyen kişinin bir eylemi gerçekleştirme niyeti ya da eyleme geçmesi halinde değil; bu suçun doğası ve bağlamı gereği bir ülkeye ya da uluslararası kuruluşa karşı ağır bir saldırı teşkil etmesi halinde bağlamsal unsurun sağlanmış sayılacağı söylenebilecektir. ${ }^{9}$ Dolayısıyla bağlamsal unsur, bir suça terör niteliğini failin yaklaşımı bakımından değil, yöneldiği sonuç bakımından vermektedir.

Terör suçları suçla hedeflenen amaç (saik), suçun işleniş biçimi (yöntem) ve suçun mahiyeti açısından karakterize edilebilecektir. ${ }^{10}$ Bu kriterler ile terör suçları, diğer suç kategorilerinden ayrılabilir.

\section{Mutlak-Nispi Terör Suçu Ayrımının Ana Hatları}

"Mutlak terör suçu" ve "nispi terör suçu” kavramları esas olarak doktrinin ürettiği kavramlar olup Terörle Mücadele Kanunu'nda bu terimler kullanılmamaktadır. Bununla beraber Yargıtay kararlarında da bu ayrımın esas alındığı görülmektedir. ${ }^{11}$ 3713 sayılı Kanun'da bu kavramlar yerine "terör suçları" (m. 3) ve "terör amacı ile işlenen suçlar” (m. 4) kavramlarının tercih edildiği görülmektedir. Söz konusu ayrıma göre Kanun'un "terör suçu” olarak adlandırdığg suçlar, "mutlak terör suçları"nı, "terör amacı ile işlenen suç" ise nispi terör suçlarını ifade etmektedir.

Terör suçlarının mutlak terör suçu ve nispi terör suçu olarak sınıflandırılması, suç teşkil eden maddi fiilin, kanunun doğrudan belirtmesi ya da kanunun belli bir tanıma bağlı olarak "terör suçu” şeklinde nitelendirilmesine dayanmaktadır.

Sadece Türk hukukunda değil, Fransız hukukunda da terör suçlarının benzer biçimde tasnif edildiği söylenebilecektir. Fransız Ceza Kanunu’nda düzenlenen terör suçlarının nispi terör suçları (terrorisme par référence) ve özerk / mutlak terör suçları (infractions terroristes autonomes) şeklinde sınıflandırıldığı gözlemlenmektedir. ${ }^{12}$ Mutlak terör suçları mahiyeti ya da kanunun doğrudan belirtmesi dolayısıyla bu kategoriye dahil olan terör suçlarıdır. Bu ayrım çerçevesinde nispi terör suçlarının da adi suçlara dayalı terörizm (terrorisme dérivé du droit commun) olarak tarif edilmesi mümkündür. ${ }^{13}$

3713 sayılı Terörle Mücadele Kanunu, 3. maddesinde sayılan suçların ayrı bir kriter aranmaksızın terör suçu olduğunu belirtmektedir. Buna karşılık, Kanun'un 4. maddesi, belli bir takım suçlara yer vermekle birlikte bu suçların terör suçu sayılmasını Kanun'un 1. maddesinde belirtilen amaçlar doğrultusunda suç işlemek üzere kurulmuş bir terör örgütünün faaliyeti çerçevesinde işlenmesi koşuluna bağlamaktadır.

8 Serna, "Des Infractions Terroristes", s.204.

9 Serna, "Des Infractions Terroristes", s.204.

10 Ahmet Ulutaş ve Ömer Serdar Atabey, Ulusal ve Uluslararası Boyutlarıyla Terörle Mücadele Hukuku, Ankara: Seçkin Yayıncılık, 2012, s.14.

11 Yakın tarihli birkaç örnek için bkz: Yargitay 16. Ceza Dairesi, E. 2017/3415, K. 2018/495, T. 16.01.2018; Yargitay 16. Ceza Dairesi, E. 2018/1339, K. 2018/1279, T. 26.04.2018; Yargıtay 16. Ceza Dairesi, E. 2018/1450, K. 2018/1893, T. 29.03.2018; Kazancı İçtihat Bilgi Bankası, http://www.kazanci.com/kho2/ibb/giris.htm, erişim tarihi: 26.10 .2018 .

12 Christophe André, Droit Pénal Spécial, 3e édition, Paris: Éditions Dalloz, 2015, s.357.

13 Romain Ollard and François Rousseau, Droit Pénal Spécial, Mesnil-sur-l’Estrée: Éditions Bréal, 2015, s.442. 
Kanun koyucunun yaklaşımı birtakım suçların terör amacı, terör yöntemi ve terör örgütü faaliyeti kapsamında işlenmesine bakılmaksızın mahiyeti gereği terör suçu olarak sayılması gerektiği yönündedir. Bu suçlar, mutlak terör suçlarıdır. Mutlak terör suçları 3713 sayılı Kanun'un 1. maddesindeki terör tanımına, deyim yerindeyse, içkindir. Buna mukabil, Kanun'un 4. maddede sayılan nispi terör suçları, suçun "niteliği”ne, "doğası”na, "kanuni tanımlarının mahiyetine” bakılırsa terör suçu değil, adi suçtur. Bununla beraber terör örgütü faaliyeti kapsamında işlenmesi bu suçlara terör suçu niteliği vermektedir.

\section{Mutlak Terör Suçları}

\section{Kavram}

Mutlak terör suçları, suçun kanuni tanımı ve mahiyeti gereği terör amacına yönelik suçlar olarak tarif edilebilir. Aşağıda belirtileceği üzere, bu suçların 3713 sayılı Kanun'un 1. maddesindeki terör tanımıyla içerik açısından ilişkileri doğrudan niteliktedir. Dolayısıyla, söz konusu 1. maddedeki terör tanımına mahiyeti gereği, bağlamsal unsur (élément contextuel) ${ }^{14}$ bakımından dahil olmayan bir mutlak terör suçundan söz edilmesi mümkün değildir. Keza kanun koyucunun bu suçlar bakımından terör örgütü faaliyetinin varlığını kanuni bir karine olarak varsaydığı da söylenebilecektir. ${ }^{15}$ Nitekim kanun koyucu, bu suçları, Kanun'un 1. maddesinde belirtilen amaçlar doğrultusunda suç işlemek üzere kurulmuş bir terör örgütünün faaliyeti çerçevesinde işlenmesi koşuluna bağlamamışs ${ }^{16}$, doğrudan terör suçu olarak düzenlemiştir. Yargıtay içtihadında da görüldüğü üzere, mutlak terör suçlarında mahkemenin uygulaması gereken 3713 sayılı Kanun'un 5. maddesinden kaynaklanan ceza artırımı, takdiri değil, zorunludur. ${ }^{17}$

Terörle Mücadele Kanun'un 3. maddesine göre, 5237 sayılı Türk Ceza Kanunu'nun 302, 307, 309, 311, 312, 313, 314, 315 ve 320. maddeleri ile 310. maddesinin birinci fikrasında yazılı suçlar, terör suçlarıdır. Devletin birliğini ve ülke bütünlügünü bozmak, askerî tesisleri tahrip ve düşman askerî hareketleri yararına anlaşma, anayasayı ihlal, yasama organına karşı suç, hükümete karşı suç, Türkiye Cumhuriyeti Hükümetine karşı silâhlı isyan, silahlı örgüt, silah sağlama, yabancı hizmetine askere yazma, yazılma ve Cumhurbaşkanına suikast suçları bu kapsamdadır. Ayrıca terör amaçlı örgütlenme suçu düzenleyen 3713 sayılı Kanun'un m. 7/1 hükmünde 5237 sayılı Kanun'un 314. maddesine yaplan gönderme ve 3713 sayılı Kanun'un 3. maddesinde 5237 sayılı Kanun'un 314. maddesine yer verilmesi dolayısıyla, terör amaçlı örgütlenme suçu mutlak anlamda bir terör suçudur.

14 Serna, “Des Infractions Terroristes”, s.204.

15 Faruk Turinay, “Ceza Hukukunda Terör Örgütü Kavramı", Türkiye Barolar Birliği Dergisi, 116 (2015), s.67.

16 Osman Serkan Gülfidan, "AİHM İçtihatları ve Demokratik Toplum Gerekleri Karşısında 5532 Sayılı Kanunla Değişik 3713 Sayılı Terörle Mücadele Kanunu”, Galatasaray Üniversitesi Hukuk Fakültesi Dergisi, 1 (2007), s.296. 17 “...suçlarının 3713 Sayılı TMK’nın 3. maddesinde düzenlenen mutlak terör suçlarından olması, aynı Kanun’un 5. maddesi kapsamında mutlak terör suçlarında her halükarda 3713 Sayılı TMK’nın 5. maddesinin herhangi bir takdir hakkı olmaksızın uygulanmasının zorunlu olduğu” Yargıtay 16. Ceza Dairesi, E. 2017/3415, K. 2018/495, T. 16.01.2018, Kazancı İçtihat Bilgi Bankası, http://www.kazanci.com/kho2/ibb/files/dsp.php?fn=16cd-2017-3415. htm\&kw=' mutlak+ter\%C3\%B6r+su\%C3\%A7`\#fm, erişim tarihi: 26.10.2018. 
Mutlak terör suçlarının ortak yönü mahiyet bakımından incelendiğinde, bu suçların doğrudan şiddet unsurunu $^{18}$ ya da şiddet tehlikesi unsurunu ${ }^{19}$ içerdiği söylenebilecektir.

Mutlak terör suçları örgütlü olarak işlenebilecek yapıda olmalarına rağmen özellikle yabancı hizmetine asker yazma, yazılma (m. 320) ve Cumhurbaşkanına suikast (m. 310/1) suçunun teorik olarak tek bir kişi tarafından işlenmesi mümkündür. Bu suçlar doğrudan mutlak terör suçu sayıldığından; bunların terör suçu niteliği taşıması için örgüt faaliyeti çerçevesinde işlenmesi koşulunun sağlanması gerekli değildir.

Genel olarak, terörle mücadeleye ilişkin düzenlemelerde, olağan ceza hükümleriyle yargılama ve infaz usullerinin dışına çıkılması ve özel hükümlerin öngörülmesi, terörün örgüt ve devamlılık unsurlarıyla ilişkilendirildiğinden, kanun koyucunun kendisinin terör yaklaşımıyla çelişmesi bakımından eleştirildiği görülmektedir. ${ }^{20}$ Yine bu doğrultuda, her ne kadar 3713 sayılı Kanundaki terör tanımı amaç, şiddet ve örgüt unsurlarına yer vermiş olsa da Kanun'un 4. maddesi uyarınca bir suçun terör suçu sayılmasında amaç unsurunun yeterli görülmesinin, kanun koyucunun yapısı gereği örgüt faaliyeti çerçevesinde işlenmesi zorunlu olmayan "tahrik ve teşvik cürümlerini terör suçu saymak istemesinden kaynaklan"dığ yönünde görüşlere rastlanmaktadır. ${ }^{21}$ Görüldüğü üzere mutlak ve nispi terör suçu tasnifi, sadece terör tanımına ilişkin değil, bir bütün olarak terörle mücadele mevzuatına ilişsin sorunlarla da iç içe geçmiş bir konumdadır.

\section{Devletin Birliğini ve Ülke Bütünlüğünü Bozmak (m. 302)}

5237 sayılı Kanun'un 302. maddesine göre, Devlet topraklarının tamamını veya bir kısmını yabancı bir devletin egemenliği altına koymaya veya Devletin bağımsızlığını zayıflatmaya veya birliğini bozmaya veya Devletin egemenliği altında bulunan topraklardan bir kısmını Devlet idaresinden ayırmaya yönelik bir fiil işleyen kimse devletin birliğini ve ülke bütünlüğünü bozmak suçunu işlemiş sayılmaktadır.

Bu suçun mutlak terör suçu olması oldukça doğaldır. Zira 3713 sayılı Kanun’un 1. maddesindeki terör tanımında "devletin ülkesi ve milletiyle bölünmez bütünlügü̈nü bozma" amacına da terörün amaçları arasında yer verildiği görülmektedir. Bu itibarla, devletin birliğini ve ülke bütünlüğünü bozma suçu, mutlak, doğal bir terör suçudur.

\section{Askerî Tesisleri Tahrip ve Düşman Askerî Hareketleri Yararına Anlaşma (m. 307)}

Askeri tesisleri tahrip suçu, 5237 sayılı Kanun tarafından Devletin silahlı kuvvetlerine ait olan veya hizmetine verilmiş bulunan kara, deniz ve hava ulaşım araçlarını, yolları, müesseseleri, depoları ve diğer askerî tesisleri, bunlar henüz tamamlanmamış

18 Bülent Tanör, “Terörle Mücadele Kanunu Üzerine İlk Düşünceler”, Milletlerarası Hukuk ve Milletlerarası Özel Hukuk Bülteni, 10/1-2 (1990), s.168.

19 Hamide Zafer, Ceza Hukukunda Terörizm, İstanbul: Beta Yayınları, 1999, s.124.

20 Zafer, Ceza Hukukunda Terörizm, s.125.

21 Zafer, Ceza Hukukunda Terörizm, s.278; Nur Centel, Hamide Zafer ve Özlem Çakmut, Türk Ceza Hukukuna Giriş, 8. Baskı, İstanbul: Beta Yayınları, 2014, s.185. 
bulunsalar bile, kısmen veya tamamen tahrip eden veya geçici bir süre için olsa bile kullanılmayacak hale getirmek olarak tanımlanmıştır. Düşman askerî hareketleri yararına anlaşma suçu ise aynı Kanun'a göre savaş zamanında Türkiye Devleti zararına olmak üzere, düşman askerî hareketlerini kolaylaştırmak veya Türkiye Devletinin askerî hareketlerine zarar vermek maksadıyla yabancıyla anlaşmak veya anlaşma olmasa da aynı sonuçları meydana getirmeye yönelik fiilleri işlemeyi ifade etmektedir.

Her iki suç askeri suçlar kapsamına girmekteyse de bu suçların yöneldiği amaç, 3713 sayılı Kanun'un terör tanımındaki Türk Devletinin ve Cumhuriyetin varlığını tehlikeye düşürmek, Devlet otoritesini zaafa uğratmak veya yıkmak veya ele geçirmek amacıyla belli ölçüde örtüşmektedir. Bir başka deyişle askeri tesislerin tahribi ve düşman askerî hareketleri yararına anlaşma ile anlaşma olmasa da düzenlemede belirtilen sonuçları meydana getirmeye yönelik fiiller, devletin varlığını tehlikeye düşürecek, devlet otoritesini zaafa uğratacak niteliktedir. Dolayısıyla, bu suçların mutlak terör suçu kapsamında sayılması, devletin birliğini ve ülke bütünlüğünü bozma suçu kadar doğrudan olmamakla beraber isabetlidir.

Anayasayı İhlal (m. 309)

Bir teşebbüs suçu olan anayasayı ihlal suçu, Kanun'da cebir ve şiddet kullanarak, Türkiye Cumhuriyeti Anayasasının öngördüğü düzeni ortadan kaldırmaya veya bu düzen yerine başka bir düzen getirmeye veya bu düzenin fiilen uygulanmasını önlemeye teşebbüs etmek olarak tarif edilmiştir.

Suçun maddi unsuru, 3713 sayılı Kanun'un terör tanımındaki "Anayasada belirtilen Cumhuriyetin niteliklerini, siyasî, hukukî, sosyal, laik, ekonomik düzeni değiştirmek" amacıyla doğrudan ve açıkça örtüşmektedir. O yüzden anayasayı ihlal suçu doğası gereği mutlak terör suçu olup kanun koyucunun 3713 sayılı Kanun'un bu suçu 3. madde kapsamında sayması kaçınılmaz bir durumdur.

Yasama Organına Karşı Suç (m. 311), Hükûmete Karşı Suç (m. 312) ve Türkiye Cumhuriyeti Hükûmetine Karşı Silahlı Issyan (m. 313)

5237 sayılı Kanun'un 311 ve 312. maddelerinde düzenlenen suçlar, cebir ve şiddet kullanarak Türkiye Büyük Millet Meclisini ve Türkiye Cumhuriyeti Hükûmetini ortadan kaldırmaya ${ }^{22}$ veya söz konusu temel anayasal kurumların görevlerini kısmen veya tamamen yapmasını engellemeye teşebbüs etmeyi ifade etmekte olup maddi unsur bakımından kurumun taşıdığı ad dışında benzer mahiyettedir.

311. ve 312. maddede düzenlenen suçların hedef aldığı kurumlar, devletin yalnızca anayasal nitelikteki değil, aynı zamanda "kurucu” organlarıdır. Türkiye Büyük Millet Meclisi, devletin yegane yasama organı iken, Türkiye Cumhuriyeti Hükûmeti devletin esas yürütme organıdır. Bu kurumların devletin varlığından ayrı telakki edilmesi mümkün değildir. Yasama organı ve yürütme organı olmayan bir devletin varlığın-

22 Yargıtay da hükûmete karşı suçu mutlak terör suçu olarak nitelendirmektedir. Yargıtay 16. Ceza Dairesi, E. 2015/3, K. 2017/3, T. 24.04.2017, https://www.kararara.com/forum/viewtopic.php?f=46\&t=232069\&start=5, erişim tarihi: 03.08.2018. 
dan söz edilemez. Bu yüzden söz konusu organlara karşı işlenen, yukarıda tanımına yer verilen suçların yöneldiği amaç, 3713 sayılı Kanun'un 1. maddesindeki terör tanımında, “Türk Devletinin ve Cumhuriyetin varlığını tehlikeye düşürmek” şeklinde ifade edilen terör amacıyla doğrudan bağlantılıdır.

5237 sayılı Kanun'un 313. maddesinde düzenlenen suç, halkı, Türkiye Cumhuriyeti Hükûmetine karşı silahlı bir isyana tahrik, silahlı isyanı idare etmek ve isyana katılmak fiillerini kapsamaktadır. Bu suç bakımından yukarıda Türkiye Cumhuriyeti Hükûmeti'ne karşı suç bağlamında belirtilen hususlar geçerlidir. Ayrıca, 3713 sayılı Kanun'daki terör tanımında yer verilen, “devlet otoritesini zaafa uğratmak veya yıkmak veya ele geçirmek, temel hak ve hürriyetleri yok etmek, Devletin iç ve diş güvenliğini, kamu düzenini bozmak" amaçları da Türkiye Cumhuriyeti Hükûmetine karşı silahlı isyan suçunun amaçlarıyla örtüşmektedir. Dolayısıyla her üç suç tipinin de terör olgusu ve amaçlarıyla bağlantısı dolaysızdır.

\section{Silahlı Örgüt (m. 314), Terör Amaçlı Örgütlenme Suçu (TMK m. 7/1) ve Silah} Sağlama (m.315)

5237 sayılı Kanun'un 314. maddesinin terör kavramıyla ilişkisi, sadece 3713 sayılı Kanun'un 3. maddesindeki mutlak terör suçları arasında yer almasından değil, aynı zamanda 3713 sayılı Kanun'un 7. maddesinin ilk fıkrasında düzenlenen terör amaçlı örgütlenme suçuyla (yaptırım ve mahiyeti içeren) atıf bağlantısından kaynaklanmaktadır.

Düzenlemeye göre, millete ve devlete karşı suçlar ve son hükümlere ayrılan dördüncü kısmın "devletin güvenliğine karşı suçlar" başlığını taşıyan dördüncü bölümü ile "anayasal düzene ve bu düzenin işleyişine karşı suçlar"1 düzenleyen beşinci bölümünde yer alan suçları işlemek amacıyla silahlı örgüt kurma, yönetme ve üye olma fiillerini kapsayan örgütlenme faaliyeti "silahlı örgütlenme suçu”nu oluşturmaktadır.

Silahlı örgütün yöneldiği amaçlar ile 3713 sayılı Kanun'un 1. maddesi karşılaştırıldığında "Anayasada belirtilen Cumhuriyetin niteliklerini, siyasî, hukukî, sosyal, laik, ekonomik düzeni değiştirmek" ve "devletin iç ve diş güvenliğini bozmak" amaçlarının tam anlamıyla örtüştüğü görülmektedir. Dolayısıyla, 314. maddedeki suçun mutlak terör suçu olması hem kanun sistematiği hem de sözü edilen amaçların içeriği bakımından kaçınılmazdır.

Terör amaçlı örgütlenme suçu, 3713 sayılı Kanun'un 7. maddesinin ilk fikrasında düzenlenmektedir. Hükme göre cebir ve şiddet kullanılarak; baskı, korkutma, yıldırma, sindirme veya tehdit yöntemleriyle, Kanun'un 1. maddesinde belirtilen amaçlara yönelik olarak suç işlemek üzere, terör örgütü kuranlar, yönetenler ile bu örgüte üye olanlar Türk Ceza Kanununun 314. maddesinde düzenlenen silahlı örgütlenme suçuna ilişkin hükümlere göre cezalandırılır. Örgütün faaliyetini düzenleyenler de örgütün yöneticisi olarak cezalandırılmaktadır. Terör amaçlı örgütlenme suçu söz konusu atıf ilişkisi nedeniyle silahlı örgütlenme suçuyla çok yakın nitelikte olup tanımı gereği mutlak terör suçudur. 
Silah sağlama suçu ise 314. maddede tanımlanan örgütlerin faaliyetlerinde kullanılmak maksadıyla bunların amaçlarını bilerek, bu örgütlere üretmek, satın almak veya ülkeye sokmak suretiyle silah temin etmek, nakletmek veya depolamaktan ibaret olup yardım etmek suretiyle iştirakin özel olarak düzenlendiği bir suç tipidir. Silahlı örgütlenme suçundan ayrı değerlendirilemeyeceği için bu suç hakkında yukarıda belirtilen hususlar, silah sağlama suçu bakımından da geçerlidir.

\section{Yabancı Hizmetine Askere Yazma, Yazılma (m.320)}

Yabancı hizmetine askere yazma, yazılma suçu, hükûmetin izni olmaksızın bir yabancı veya yabancı Devlet hizmetinde veya bunların lehinde çalışmak üzere ülke içinde vatandaşlardan asker almak veya vatandaşları silahlandırmak olarak tanımlanmaktadır. Yabancı hizmetine askere yazma, yazılma suçunun mahiyetinin terör olgusu ve amacıyla doğrudan ilişkilendirilmesi ilk bakışta yukarıda yer verilen suçlar kadar kolay olmamakla birlikte, asker toplama ve asker olarak hizmet verme faaliyetinin, terör tanımındaki "devletin iç ve dış güvenliğini, kamu düzenini bozmak" amacına matuf bir nitelik taşıdığı, özellikle yabancı devlet hizmetinde bu faaliyetlerin yürütülmesi bakımından bu suçun mutlak terör suçu sayılmasının isabetsiz olmadığı söylenebilecektir.

\section{Cumhurbaşkanına Suikast (m.310/1)}

Ceza kanunları çok nadir olarak belli bir sıfatı taşıyan kişiye karşı işlenen fiilleri özel olarak düzenler. Cumhurbaşkanına suikast suçu da 5237 sayılı Kanun'daki istisnai düzenlemeyi oluşturmaktadır.

Cumhurbaşkanının Anayasa’ya göre devletin başı olması (AY m. 104/1), devlet başkanı sıfatıyla Türkiye Cumhuriyetini ve Türk Milletinin birliğini temsil etmesi (AY m. 104/2) bu düzenlemenin hukuki ve mantıksal gerekçesi olarak değerlendirilebilir. Cumhurbaşkanının söz konusu anayasal nitelikleri, ona karşı işlenen "suikast" fiilinin doğal amaçlarıyla, 3713 sayılı Kanun'daki terör tanımında yer verilen "devlet otoritesini zaafa uğratmak", devletin iç ve dış güvenliğini bozmak” amaçlarının örtüşmesinin mantıksal dayanağı olarak gösterilebilecektir. Bu itibarla, Cumhurbaşkanına suikast suçunun mutlak terör suçu sayılması, hukuk tekniği ve suçla korunan hukuki değer bakımından tutarlı görünmektedir.

\section{Nispi Terör Suçları}

\section{Kavram}

Nispi terör suçları kural olarak terör suçu değil, adi suç niteliğindedir. Bu suçlar, terör dışında herhangi bir saikle ya da saik olmaksızın işlendiklerinde adi suç olma özelliklerini korumaktadır. Fakat sözü edilen suçlar, ancak ve ancak "terör amaç ve yöntemleriyle hareket eden bir suç örgütünün faaliyeti kapsamında” işlenmesi halinde terör suçu sayılmaktadır. 


\section{Düzenlemenin Mahiyeti}

Terör örgütleri her zaman anayasayı ihlal, hükûmete karşı suç, Cumhurbaşkanına suikast gibi suçları işlemek suretiyle faaliyet göstermezler. Terör örgütlerinin işledikleri ya da işleme potansiyeli taşıdıkları suçlar arasında kasten öldürmeden orman yakmaya, eziyetten genel güvenliğin kasten tehlikeye sokulmasına, kıt’a sahanlığında veya münhasır ekonomik bölgedeki sabit platformların işgalinden gözaltına alınanın veya tutuklunun kaçmasını sağlamaya kadar çok çeşitli suçlar yer almaktadır. Kanun koyucu bu sebeple pek çok adi suçu belli hallerde terör suçu sayılabilecek kapsamda düzenlemiştir.

3713 sayılı Kanun'un 4. maddesine göre, aynı Kanun'un 1. maddesinde belirtilen amaçlar doğrultusunda suç işlemek üzere kurulmuş bir terör örgütünün faaliyeti çerçevesinde işlendiği takdirde, terör suçu sayılacak nispi terör suçları şunlardır:

a) Türk Ceza Kanununun 79, 80, 81, 82, 84, 86, 87, 96, 106, 107, 108, 109, 112, 113 , $114,115,116,117,118,142,148,149,151,152,170,172,173,174,185,188,199$, 200, 202, 204, 210, 213, 214, 215, 223, 224, 243, 244, 265, 294, 300, 316, 317, 318 ve 319 'uncu maddeleri ile 310 'uncu maddesinin ikinci fikrasında yer alan suçlar.

b) 10/7/1953 tarihli ve 6136 sayılı Ateşli Silahlar ve Bıçaklar ile Diğer Aletler Hakkında Kanunda tanımlanan suçlar.

c) 31/8/1956 tarihli ve 6831 sayılı Orman Kanununun 110'uncu maddesinin dördüncü ve beşinci fikralarında tanımlanan kasten orman yakma suçları.

ç) 10/7/2003 tarihli ve 4926 sayılı Kaçakçlıkla Mücadele Kanununda tanımlanan ve hapis cezasını gerektiren suçlar.

d) Anayasanın 120'nci maddesi gereğince olağanüstü hal ilan edilen bölgelerde, olağanüstü halin ilanına neden olan olaylara ilişkin suçlar.

e) $21 / 7 / 1983$ tarihli ve 2863 sayılı Kültür ve Tabiat Varlıklarını Koruma Kanununun 68 'inci maddesinde tanımlanan suç.

Yukarıda da vurgulandığı üzere, nispi anlamda terör suçlarının çok çeşitli olduğu açıktır. Hayata karşı suçlar, malvarlığına karşı suçlar, genel tehlike yaratan suçlar, kamu güvenine karşı suçlar, kamu barışına karşı suçlar, bilişim alanında suçlar gibi çok çeşitli suç kategorilerine giren fiiller, terör saikiyle ve bir terör örgütünün faaliyeti çerçevesinde işlenmesi koşuluyla terör suçu kabul edilmektedir.

Kanun koyucunun nispi terör suçlarını düzenlerken bazı hallerde suçun ağırlığ1nı gözettiği de görülmektedir. Örneğin Cumhurbaşkanına suikast suçu (m. 310/1) mutlak terör suçu olarak düzenlenmişken, Cumhurbaşkanına fiili saldırı suçu (m. 310/2) nispi terör suçu olarak düzenlenmiştir.

3713 sayılı Kanun'un nispi terör suçlarına ilişkin 4. maddesi, 2006 yılında 5532 sayılı Kanun'la değiştirilmiş olup bu düzenlemeden önce madde metni yalnız 1. maddedeki terör amacı unsuruna atıf yapmakta ve örgüt unsuruna yer vermemekteydi. Bu 
durum ise o dönemde doktrinde eleştirilmekteydi. ${ }^{23} 5532$ sayılı Kanun'la yapılan değişiklikle söz konusu suçların terör tanımı kapsamındaki amaçlar doğrultusunda suç işlemek üzere kurulmuş bir terör örgütünün faaliyeti çerçevesinde işlendiği takdirde terör suçu sayılacağı düzenlenerek; örgüt unsuru nispi terör suçları kategorisinin kriteri olarak sayılmış, ayrıca terör amaçlı örgütlenme ve terör örgütü kavramıyla 1. madde düzenlenen terör amacı arasında doğrudan bağlantı kurulmuştur. 5532 sayılı Kanun'un öngördüğü değişikliğin nispi terör suçları açısından, tek başına hareket eden failler ile terör örgütleri arasında yapay bağlantılar kurulması ihtimaline karşı bir hukuki bir önlem olarak değerlendirildiği söylenebilir. ${ }^{24}$

5532 sayılı Kanun tasarısında değişiklik gerekçesi şu şekildedir:

Terörle Mücadele Kanununun 4'üncü maddesinde yapılan değişiklikle, terör örgütünün faaliyeti çerçevesinde işlenen çeşitli suçların da terör suçu sayılacağ kabul edilmiştir. Çeşitli suçlar, mahiyeti gereğince cebir, şiddet veya tehdit içermeseler bile bir terör örgütünün faaliyeti çerçevesinde işlenmeleri halinde terör suçu sayılacaklardır. Örneğin, uyuşturucu madde imal ve ticareti, belgede sahtecilik, parada sahtecilik, kaçakçılık gibi suçlar bir terör örgütünün faaliyeti çerçevesinde sıklıkla işlenebilmektedirler. 3713 sayılı Kanunun 4'üncü maddesinin mevcut metninde mülga 765 sayılı Türk Ceza Kanununda yer alan sınırlı suç maddesine yollamada bulunulduğu için, bu örnek suçlar terör suçu olarak kabul edilememektedir. Bu durum özellikle görevli mahkemenin belirlenmesi açısından bir sorun oluşturmaktadır. Örneğin terör örgütünü kurmak ve yönetmek suçundan dolayı açılan dava özel yetkili bir mahkemede görülürken, bu örgütün faaliyeti çerçevesinde işlenen belgede sahtecilik suçuna ilişkin davaya genel yetkili mahkemelerde bakılmaktadır. Bu sakıncanın önüne geçebilmek amacıyla madde metninde değişiklik yapılmıştır. $\mathrm{Bu}$ değişikliğe göre, söz konusu 4’üncü madde metninde 5237 sayılı Türk Ceza Kanununun atıfta bulunulan maddelerinde tanımlanan suçların bir terör örgütünün faaliyeti çerçevesinde işlenmiş olması halinde terör suçu sayılması mümkün olacaktır. ${ }^{25}$

Tasarıdaki nispi suçların çok kapsamlı olması eleştirilmiştir. Bu eleştiri doğrultusunda tasarıdaki metin yeniden düzenlenmiş, "kasten öldürme ve yaralama suçları, cebir ve şiddet içeren suçlar” ibaresi ile bazı suç tipleri metinden çıkarılmış, kasten öldürme ve yaralama suçları, cebir ve şiddet içeren söz konusu suçların ise madde numaralarına metinde yer verilerek ${ }^{26}$ nispi terör suçlarının kapsamı daraltılmış ve somutlaştırılmıştır. Bu değişikliğin kanunilik ilkesi bakımından isabetli olduğu kanaatindeyiz.

Öte yandan nispi terör suçlarının kapsamının dar olduğu yönünde bir eleştiriye de rastlanmaktadır. Bu görüşe göre terör amacıyla işlenen suçlar kapsamında 5237

23 Zafer, Ceza Hukukunda Terörizm, s.125.

24 Nevzat Toroslu, "Ceza Hukuku Açısından Terörle Mücadele Yasası”, Terörle Mücadele Yasası ve İnsan Hakları, Ankara: İnsan Hakları Derneği Yayınları, 1991, s.21.

25 Vahit Baltacı, Yeni TCK ve CMK'da Terör Suçları ve Yargılaması, Ankara: Seçkin Yayıncılık, 2007, s.324.

26 Baltacı, Yeni TCK ve CMK'da Terör Suçları ve Yargılaması, s.324. 
sayılı Türk Ceza Kanunu’nun 220. maddesinde düzenlenen genel amaçlı örgütlenme suçuna yer verilmemesi “önemli bir eksikliktir”" ${ }^{27}$ Bu görüşe katılmamaktayı; çünkü örgütlenme suçu terör saikiyle olduğunda terör amaçlı örgütlenme suçunu oluşturmakta olup bu suç zaten mutlak terör suçu teşkil etmektedir.

Nispi anlamda terör suçları kategorisi, terör örgütü faaliyeti kapsamında işlenme kriterine, dolayısıyla böyle bir terör örgütünün varlığına doğrudan bağlıdır. Bu bağlamda hukuk güvenliği bakımından terör amaçlı örgütlenme faaliyetinin hukuki niteliğinin açıkça saptanmaması halinde "terör suçları" kategorisinin kanun koyucunun amacını aşacak şekilde genişlemesi mümkün görünmektedir. Dolayısıyla nispi terör suçlarının ceza mahkemelerince değerlendirilmesinde bu hususun üzerinde önemle durulması zorunludur.

Nispi terör suçu olma kriteri bakımından ayrıca not etmek gerekir ki "terör örgütünün faaliyeti çerçevesinde" işlenen fiiller tabiri, "terör örgütünün faydasına işlenen" veya "terörle ilgili" fiiller şeklinde ifade edilen kategorilerden farklı olup daha dar kapsamlidir. ${ }^{28}$

\section{Sonuç}

Terör suçu kavramı öncelikle terör ve terörizmin tanımının muğlaklığından dolayı tanımlanması güç bir kavramdır. İkinci olarak terör suçunun bir suç kategorisi olarak, örneğin hayata karşı suçlar ya da malvarlığına karşı suçlar kategorilerinde olduğu gibi belirgin, sınırlayıcı, basit ve somutlaştıcı bir tarifini yapmak güçtür.

Terör suçlarının mutlak terör suçu ve nispi terör suçu olarak sınıflandırılması, ceza hukukunun inceleme alanına giren suçların hukuki yapısından kaynaklanmaktadır. Şöyle ki, bazı suçlar kanundaki hukuki tanımı ve mahiyeti gereği terör olgusuyla iç içeyken, başka bazı suçlar da ilk bakışta terör olgusuyla doğrudan ilgili görünmemektedir. Bu yüzden, ilk kategoride yer alan, terörün tanımıyla örtüşen mahiyete sahip suçlar mutlak terör suçu olarak görülmekte; terör olgusuyla mahiyet bakımından örtüşmediği halde "terör amacı ve yöntemiyle" hareket eden bir terör örgütü faaliyeti kapsamında işlendiğinde artık hukuki anlamda bir terör suçundan söz etmek gerektiği için nispi terör suçu olarak adlandırılmaktadır.

Pek çok suç mutlak terör suçu olmaya elverişli değildir. Buna mukabil, gerek Türk Ceza Kanunu'nda, gerekse özel ceza kanunlarıyla suç ve ceza içeren diğer kanunlarda düzenlenen çok sayıda suç, terör örgütü kapsamında işlenmeye elverişlidir. Dolayısıyla nispi terör suçlarının mutlak terör suçlarına göre çok daha geniş kapsamlı olduğunu belirtmek gerekir. Nitekim 3713 sayılı Kanun'un 3. ve 4. maddesi incelendiğinde bu olgunun düzenlemelere yansıdığı görülmektedir.

Bir suçun terör suçu olması, 3713 sayılı Kanun'un 5. maddesi uyarınca cezanın ağırlaştırılması sonucu yaratması itibariyle özel bir önem arz etmektedir. Bu hükme göre 3713 sayılı Kanun'un 3. ve 4. maddelerinde yazılı suçları işleyenler hakkında ilgili

27 Hikmet Sami Türk, Terörizmle Mücadelenin Hukuki Boyutları, Ankara: Yetkin Yayınları, 2012, s.7.

28 Baltacı, Yeni TCK ve CMK'da Terör Suçları ve Yargılaması, s.325. 
kanunlara göre tayin edilecek hapis cezaları veya adlî para cezaları yarı oranında artırılmakta, bu suretle tayin olunacak cezalarda, gerek o fiil için, gerek her nevi ceza için muayyen olan cezanın yukarı sınırı aşılabilmekte, müebbet hapis cezası yerine ise ağırlaştırılmış müebbet hapis cezasına hükmolunmaktadır. Mutlak terör suçları bakımından bu nitelik doğrudan etkiliyken nispi terör suçları bakımından söz konusu Kanun'un 1. maddesi esas alınmaktadır. Bu bağlamda nispi terör suçlarından kurulacak mahkumiyet hükümlerinde "terör örgütü" olgusunun ve işlenen suçun "terör örgütü faaliyeti kapsamında" işlenmesinin önemi çok büyük ve hukuk devleti ilkesi ve suçta ve cezada kanunilik prensibi bakımından çok daha hassastır. Yarg1 mercilerinin bu hususta özel bir duyarllılı göstermeleri, ceza hukuku vasitasılya terörle mücadele faaliyetlerinin etkililiği, meşruiyeti ve sürdürülebilirliği bakımından lüzumludur.

\section{Kaynakça}

Alparslan, Şükrü. Hukuk ve Kriminoloji Açısından Tedhişçilik. İstanbul: Teknik Yayınları, 1983.

André, Christophe. Droit Pénal Spécial. 3e édition, Paris: Éditions Dalloz, 2015.

Baltacı, Vahit. Yeni TCK ve CMK'da Terör Suçları ve Yargılaması. Ankara: Seçkin Yayıncilik, 2007.

Centel, Nur, Hamide Zafer ve Özlem Çakmut. Türk Ceza Hukukuna Giriş. 8. Baskı, İstanbul: Beta Yayınları, 2014.

De la Serna, Ignacio. "Des Infractions Terroristes". Eds. Christian De Valkeneer and Ignacio de la Serna. À la Découverte de la Justice Pénale: Paroles de Juriste. Bruxelles: Éditions Larcier, 2015, 199-233.

Gülfidan, Osman Serkan. "AİHM İçtihatları ve Demokratik Toplum Gerekleri Karşısında 5532 Sayılı Kanunla Değişik 3713 Sayılı Terörle Mücadele Kanunu”. Galatasaray Üniversitesi Hukuk Fakültesi Dergisi. 1 (2007): 257-328.

Navarrete, Miguel Polaino. “Apología y Encubrimiento del Terrorismo". Ed. Faustino Gutiérrez and Alviz Conradi. La Criminalidad Organizada Ante la Justicia. Sevilla: Editorial Universidad de Sevilla, 1996, 37-52.

Ollard, Romain and François Rousseau. Droit Pénal Spécial. Mesnil-sur-l'Estrée: Éditions Bréal, 2015.

Özek, Çetin. “Terör ve Terörle Mücadele Kanunu”. İstanbul Barosu Dergisi. 65/4-5-6 (1991): 352-385.

Taner, Tahir. «Tedhiş̧̧ilik ve 16 İkinci Teşrin 1937 Cenevre Mukavelenameleri». İÜHFM. (Cemil Birsel’e Armağan). 1939, 461-487.

Tanör, Bülent. "Terörle Mücadele Kanunu Üzerine İlk Düşünceler”. Milletlerarası Hukuk ve Milletlerarası Özel Hukuk Bülteni. 10/1-2 (1990): 165-173.

Toroslu, Nevzat. “Ceza Hukuku Açısından Terörle Mücadele Yasası”. Terörle Mücadele Yasası ve İnsan Hakları. Ankara: İnsan Hakları Derneği Yayınları, 1991, 19-29.

Turinay, Faruk. "Ceza Hukukunda Terör Örgütü Kavramı". Türkiye Barolar Birliği Dergisi. 116 (2015): 39-84. 
Türk, Hikmet Sami. Terörizmle Mücadelenin Hukuki Boyutları. Ankara: Yetkin Yayınlar1, 2012.

Ulutaş, Ahmet ve Ömer Serdar Atabey. Ulusal ve Uluslararası Boyutlarıyla Terörle Mücadele Hukuku. Ankara: Seçkin Yayınclık, 2012.

Zafer, Hamide. Ceza Hukukunda Terörizm. İstanbul: Beta Yayınları, 1999. 


\title{
The Absolute and Relative Crimes of Terrorism according to the Turkish Counter Terrorism Law
}

FARUK Y. TURINAY

\begin{abstract}
The phenomenon of terrorism is known as a concept which is hardly defined in the national and international contexts. We come across with this difficulty in defining by laws the terrorist association, the acts which create the crime of terrorist association and the crimes of terrorism. In this study, the concept of the crime of terrorism as defined in the framework of Turkish Counter Terrorism Law is mentioned as the absolute crimes of terrorism and the relative crimes of terrorism. The first part of this study deals with the concept of the crime of terrorism and a general approach to the differences between the absolute crimes of terrorism and the relative crimes of terrorism. In the second part of this study, the absolute crimes of terrorism in the Turkish Penal Code - Disrupting the Unity and Integrity of the State, Destruction of Military Facilities and Conspiracy which Benefits Enemy Military Movements, Violation of the Constitution, Offences against the Legislative Body, Offences against the Government, Armed Revolt against the Government of Turkish Republic, Armed Organisation, Supplying Arms, Enlistment of Soldiers in Foreign Service, Assasionation of the President and the crime of terrorist organization-are examined according to the Turkish Counter Terrorism Law. The conceptual and legal framework of the relative crimes of terrorism is mentioned in the last part of the study.
\end{abstract}

Keywords: Absolute crimes of terrorism, The relative crimes of terrorism, Turkish Counter Terrorism Law, Turkish Penal Code. 